\title{
The Environmental, Social and Economic Impacts of Cruising and Corporate Sustainabilty Strategies
}

\author{
By Peter Jones* \\ David Hillier ${ }^{\dagger}$ \\ Daphne Comfort
}

\begin{abstract}
As the popularity and geographical reach of ocean cruising continues to increase so its environmental, social and economic impacts are growing in scale. With this in mind the aims of this paper are to offer an exploratory review of the extent to which the leading ocean cruise companies are addressing and reporting on their sustainability strategies and achievements and to offer some reflections on sustainability within the cruising industry. The paper begins with an outline of cruising and the cruising industry and a short commentary on the sustainability challenges the industry faces. The information on which the paper is based is drawn from the leading cruise companies' corporate web sites. The findings of the paper reveal a marked variation in the extent to which the leading cruise companies publicly report on their sustainability strategies and achievements. While the two leading cruise companies, namely the Carnival Corporation and Royal Caribbean Cruises, published extensive sustainability reports which covered a number of environmental social and economic issues, the other leading cruise companies published more limited information on sustainability. More critically the authors argued that the cruise companies' commitments to sustainability are driven by the search for efficiency gains and are couched within existing business models centred on continuing growth than on maintaining the viability of natural ecosystems and communities.
\end{abstract}

Keywords: ocean cruising, sustainability, environment: corporate citizenship, economic growth

\section{Introduction}

The origins of modern day ocean cruising as a tourist activity can been traced back to the late 1960's and early 1970's (World Tourism Organization, 2010) and since then cruising has grown rapidly to become an increasingly important and high profile element in the tourist market. In 2015 an estimated 22 million passengers took a cruise and generated an estimated $£ 27$ billion in revenue (Cruise Market Watch, 2015). The geography of cruising has expanded from its origins in the Caribbean (Wood 2000) to embrace most parts

\footnotetext{
* Professor of Management, The Business School, University of Gloucestershire, UK.

${ }^{\dagger}$ Emeritus Professor, The Centre for Police Sciences, University of South Wales, UK.

${ }^{\ddagger}$ Research Administrator, The Business School, University of Gloucestershire, UK.
} 
of the world and Rodrigue \& Notteboom (2013,p. 13)) have argued that cruising has 'become the salient symbol of the globalization of the tourist industry in terms of its coverage, its practices and the mobility of its assets.' Given cruising's increasingly global reach its environmental, social and economic impacts are growing in scale. With this in mind the aim of this paper is to offer an exploratory review of how the leading ocean cruising companies are looking to manage these impacts as part of their sustainability strategies.

\section{Cruising}

While the oceans have provided a means of transport for peoples from around the world for thousands of years but, warfare apart, cargo rather than people dominated this traffic and it was not until the early nineteenth century that the origins of modern day cruising began to emerge. (Histories of specific passenger and cruise companies can be found, for example, in Anderson 1964 and Howarth \& Howarth 1986). In 1818 the US based Black Ball Line established the first scheduled ocean going passenger service established between England and the United States and began to be concerned with the comfort of its passengers (Cruising the Past, 2008). During the 1840's, The Peninsula and Oriental Steam Navigation Company (P\&O), whose initial focus was mail delivery, introduced leisure excursions when passengers from England travelled with the Royal Mail to ports on the Iberian Peninsula and the Mediterranean (P\&O Cruises, 2016). The second half of the nineteenth century saw improvements in the quality of the seaborne experience for passengers and by the early twentieth century ever larger ships were being built with an emphasis on the comfort of the passengers and on elegance and the idea of sailing as a romantic experience. By the early twentieth century ocean liners were larger and more luxuriously furnished and though the sinking of the Titanic in 1912 was a sharp reminder of the dangers of ocean travel it led to the introduction of stricter maritime safety standards. World War I saw a halt to the construction of cruising ships and many cruise ships were used as troop carriers but by the 1920s and 1930s leisure cruising regained its popularity and in 1922 the Laconia, owned by the Cunard Line, made the first world cruise which lasted six months. During World War II the cruise liners were once again used as troop carriers and many were destroyed but the large new ships built in the 1950s and 1960s benefited from advances in ship construction technology and logistics support made during the war years.

Modern day ocean cruising emerged in the late 1960s and early 1970s and coincided with the decline of scheduled ocean going passenger services and the rapid development of scheduled long distance air services and the leading passenger shipping companies effectively began to reinvent cruising as a vacation rather than primarily as a means of transport. Ocean cruising grew relatively moderately during the 1970s and 1980s but in the decades since it has consistently grown rapidly and has become an iconic and a dynamic niche within the leisure tourism market, continually extending and enhancing its 
product and its service offer and developing new markets. The geography of ocean cruising now embraces the Caribbean, the Mediterranean and the Atlantic Islands, Northern Europe, Canada and Alaska, Dubai and the Arabian Gulf, Asia and the Pacific, Australia and New Zealand, South America and Antarctica. Cruising is currently a leisure pursuit for the affluent with North America accounting for almost $60 \%$ of all cruise passengers and Europe accounting for a further $25 \%$.

As the popularity of cruising has grown so ownership patterns have become increasingly concentrated largely through merger and acquisition activity. Two major companies, namely Carnival Corporation and Royal Caribbean Cruises, currently dominate the ocean cruising market accounting for some $47 \%$ and $23 \%$ of cruise passengers (Market Realist, 2015). Originally founded in 1972 Carnival Corporation operates a number of distinct brands including Carnival Cruise Line, Princess Cruises, Cunard, Costa Cruise, and P\&O Cruises. Royal Caribbean Cruises also operates number of brands namely Royal Caribbean International, Celebrity Cruises, Pullmantur Cruises, Azamara Club Cruises and CDF Croiseres de France. Cruise ships vary in size but the larger vessels can carry up to 6,000 passengers and offer a wide range of facilities including shops, restaurants, cafés and pubs, nightclubs, discos, casinos, theatres and cinemas, libraries, gyms, swimming pools and tennis courts and offer a wide range of leisure activities. The cruise companies generally offer a variety of packages and experiences ranging from 'mini' cruises for between 2 and 5 days to round the world cruises spanning over 3 months.

\section{Environmental, Social and Economic Impacts}

As the popularity and geographical reach of cruising has grown so has its environmental, social and economic impacts and there is growing interest and scrutiny from governments, investors, environmental pressure groups and the media about the management of these impacts. Such interest is part of much wider concerns that 'the transition to more sustainable patterns of production and personal consumption is not optional' (Deloitte, 2012, p1). In a similar vein Lubin \& Esty (2010, p.3) have argued that 'customers in many countries are seeking out sustainable products and services or leaning on companies to improve the sustainability of traditional ones' and that 'managements can no longer ignore sustainability as a central factor in their companies' long-term competitiveness.' More specifically the Sustainability Accounting Standards Board (SASB), for example, whose mission is to help companies provide decision-useful information to investors, recognised cruising as the single fastest growing segment of the tourist industry' and argued that 'the environmental and social impacts of the industry are growing in scale' (Sustainability Accounting Standards Board, 2014, p. 2). The SASB further argued that management or mismanagement of these impacts 'has the potential 
to effect company valuation through impacts on profit, assets, liabilities and cost of capital' (Sustainability Accounting Standards Board, 2014, p.2)

Environmentally the impacts associated with large cruise ships include the emission of greenhouse gases, which contribute to climate change, waste from ships, which causes pollution and reduces the resilience of marine ecosystems and damage to fragile coastal and marine environments. While it is important to recognise that all shipping traffic generates environmental impacts, cruise ships create disproportionate impacts because they carry thousands of passengers who produce their own personal waste streams. Cruise ships which carry thousands of people in close proximity to each other can provide an environment for the rapid spread of contagious diseases and outbreaks of gastroenteritis and less commonly of Norovirus and Legionnaires Disease, can be a serious cause for concern. In some ways the social and economic impacts of cruising are interlinked. The increasing numbers of cruise ship tourists generate a range of economic benefits to host economies and communities, including port expenses and the purchase of fuel, water, food and beverage supplies as well as passenger expenditure in cafes, restaurants, excursions and souvenirs. However, cruise ships can also contribute to changes in traditional value systems, lifestyles and behaviours at destinations. Cruise ships can be an important source of employment, both aboard ship and on shore, and while a number of cruising companies employ people from the destinations they visit, low pay, long hours, insecurity and exploitation are currently commonplace.

That said the environmental, social and economic impacts of cruising and the development of sustainability strategies and programmes within the cruising industry have received limited attention within the academic literature. Johnson (2002, p. 261) stressed that cruising's 'socio-economic, cultural and environmental considerations need to be continually analysed' as a contribution to 'achieving sustainable tourism.' Johnson (2002, p. 261) concluded that secondary evidence suggested that the cruise industry was taking some belated but positive steps to address their environmental impacts but suggested that 'decision makers in cruise tourism destinations' needed to work more closely with cruise operators 'to facilitate both integrated waste management and intergenerational and intra-societal equity rather than merely accept the prospect of short-term economic gain.' Butt (2007, p.591)estimated that cruise ships are responsible for $25 \%$ of all waste generated by the world's merchant fleet and following his investigation of the impacts of this waste for ports concluded that 'all cruise vessels should vigorously pursue a waste reduction strategy' and that ports should 'provide adequate recycling, reduction and re-use facilities.'

Brida \& Zapata (2010, p. 224) examined a range of the economic, environmental, social and cultural effects of cruise tourism on destinations and by way of a conclusion they suggested that 'ensuring the sustainable development of a cruise destination has a very high cost' and questioned if 'the benefits of attracting cruises to a tourism destination are higher than the costs.' Klein (2011, p. 107) used case study examples to examine the impact of the growth of cruise tourism on coastal and marine environments, local 
economies and on the sociocultural dynamics of port environments. Having reviewed a range of impacts including wastewater treatment, solid waste, air emissions from fuel, the distribution of benefits, sociocultural authenticity and the homogenisation of the port experience, Klein (2011, p. 114) concludes that using 'the responsible tourism lens' is a 'useful exercise' in that 'it helps focus the analysis of sustainability on the local community and stakeholders that are affected by cruise tourism.'

Some work has also been undertaken on the impact of cruise tourism in specific regions. In reviewing the negative impact of cruise tourism in Polar Regions, Luck et al. (2010), for example, argued that the overall response to the environmental and social impacts had been woefully inadequate and suggest that cruise companies, governments, regulators and local communities need to work together to protect the fragile environment of the polar world. Stewart \& Draper (2006, p. 77) examined the elements of management and planning deemed to be important in the development of sustainable cruise tourism in Arctic Canada and concluded that stakeholders might benefit from cruise tourism management and planning being given higher priority in approaches to integrated coastal management.' Wood (2000, p. 345) examined the 'deterritorialization, cultural theming and simulation' as a manifestation of 'globalization at work in the Caribbean cruise industry.' He argued, for example, that 'the Caribbean cruise rests on many processes of economic and political deterritorialization' (Wood, 2000, p. 358) including freedom from political regulations, the ability to draw on a global pool of labour unconnected to the local region and limited dependence on the ports of call.

\section{Method of Enquiry}

In an attempt to review how the leading ocean cruising industry are looking to address and manage their environmental, social and economic impacts as part of their sustainability strategies, the ten leading cruise companies namely Carnival Corporation, Royal Caribbean Cruises, Norwegian Cruise Line, MSC Cruises, Disney Cruises, Thomson Cruises, Star Cruises, Hurtigruten, Crystal (acquired by Genting in May 2015) and Silversea, as measured by revenue, (Statista, 2015) were selected for study. As the leading players within the cruising industry the selected companies might be seen to reflect contemporary approaches to sustainability within the sector and be keen to publicise their sustainability initiatives to a wide audience. Increasingly large companies employ the internet to report on their sustainability strategies and achievements. This led the authors to conduct a digital internet search for information, using the key phrase 'sustainability report' and the name of each of the selected cruise companies. This search was undertaken in April 2016, employing Google as the search engine, and the most recent information obtained via this search formed the empirical material on sustainability strategies and achievements for this paper. 
A number of authors have employed content analysis to interrogate corporate websites and sustainability reports but in this paper the authors took the decision to tease out the key themes and narratives by a close inspection of the most recently published sustainability reports and the information on the selected companies' web sites. In taking this decision, the authors were minded of the need to discover, rather than to attempt to precisely measure, the companies' approach to sustainability. While the precise pattern of search and navigation varied from one ocean cruising company to another the authors were essentially guided by loose grounded theory in that they selected and grouped sustainability themes and issues identified on the selected websites. The information obtained through this search process provided the empirical information for this paper. The aim of this paper is not to offer a systematic and detailed comparative analysis of the selected ocean cruising companies' approaches to sustainability and the specific examples and quotations are employed for illustrative purposes. The authors openly recognise that the approach chosen has its limitations in that there are issues in the extent to which a company's published reports fully reflect strategic corporate thinking and whether or not such reports may represent thoughtfully constructed public relation exercises. That said the authors believe that their approach offers a suitably robust approach for the purposes of the present study.

\section{Sustainability Strategies and Achievements}

There are marked variations in the extent to which the leading cruise operators report and provide information on their sustainability strategies and achievements. These variations in the nature and detail of the reporting process make it difficult to compare the findings in a quantitative or tabular format. Only the two major ocean cruising companies, namely Carnival Corporation and Royal Caribbean Cruises, posted dedicated annual sustainability reports. Seven companies, namely Norwegian Cruise Lines, MSC Cruises, Disney Cruises, Thomson Cruises, Star Cruises, Genting and Silversea, published some limited information on sustainability while Hurtigruten published no information on their approach to sustainability. The two leading cruise companies outlined their sustainability strategies. The Carnival Corporation, for example, claimed to address environmental, social and economic impacts and reported that 'our reputation and success depends on having sustainable and transparent operations' and claimed that 'given our global reach and the vast impact on our guests, employees and the environment, we have developed a robust commitment to sustainability' (Carnival Corporation, 2014, webpage). Some of the other leading companies focussed more specifically on the environmental impacts of their operations. Norwegian Cruise Lines, for example, claimed that 'for more than four decades', the company 'has committed to the protection of the oceans through sustainable environmental practices, investments in technology and a commitment to exceed regulatory 
requirements, fulfilling its core company value of Environmental Protection' (Norwegian Cruise Lines, 2014, webpage).

A number of environmental issues were addressed, albeit to varying degrees, by the cruise companies including energy efficiency and greenhouse gas emissions, water and wastewater management, waste and chemical management, public health, biodiversity, conservation and sustainable tourism. Royal Caribbean Cruises, for example, reported that 'environmental stewardship is engrained in our company history' and that 'our commitment to the environment extends throughout our organization' (Royal Caribbean Cruises, 2014, webpage). More specifically Royal Caribbean Cruises argued that improving the way our ships move through the water is a critical element in our quest for sustainable energy efficiency' (Royal Caribbean Cruises, 2014, webpage) and reported on its progressive installation of more efficient rudderpropeller systems throughout its fleet. In a similar vein, the company also reported on its commissioning of new designs and technologies to reduce carbon dioxide emissions. Both companies reported commissioning limited independent assurance of their greenhouse gas emissions inventory.

Water consumption is a vital resource for cruise liners being used for swimming pools, jacuzzis and spas, cooking, cooling water, personal hygiene and cleaning. Fresh water is normally not bunkered in areas suffering from water stress and thus the focus is on both the reduction in water use and wastewater management. Carnival Corporation, for example, reported on its commitment to reducing water use throughout its fleet, without affecting the customer experience, on the setting of annual water reduction targets ranging from $1 \%$ to $5 \%$ and on promoting desalination and wastewater treatment. Royal Caribbean Cruises recognised that 'managing the amount of waste we land ashore from our ships is a key part of our commitment to protecting the global environment' (Royal Caribbean Cruises, 2014, webpage) and here the focus is on reducing, reusing and recycling solid waste, including food waste and plastics and the company claimed to work with its suppliers wherever possible to reduce packaging and to recycle as much waste as possible on board ship. In addressing waste minimisation, Disney Cruises reported that 'great care is taken onboard all Disney ships to reduce waste' and outlined the company's focus on the recycling of metals, plastic, glass and paper, its recycling of naturally occurring condensation from its ships' air conditioning system to supply fresh water for the on board laundry facilities and for cleaning purposes and the offloading and recycling of used cooking oil (Disney Cruise Line, 2014). The Carnival Corporation reported that 'all our ships have a waste management plan that specifies how we manage each type of waste on board' (Carnival Corporation, 2014, webpage).

A concern for the health and safety of both passengers and employees is an important consideration. Public health on cruise ships, for example, is subject to a range of local, national and international guidelines and regulations. Royal Caribbean Cruises, for example, reported on its work to ensure compliance with the US Centres for Disease Control and Preventions 'Vessel Sanitation Program' which includes protection and inspection criteria communicable 
disease prevention and management, gastrointestinal illness, food safety and pest management. (Current reports on individual ships and company responses to these reports are posted by Centres for Disease Control and Prevention, 2016). More generally Carnival Corporation stressed its 'obligation to protect the earth 's biodiversity' (Carnival Corporation, 2014, webpage) and it reported on its work to prevent negative impacts on habitats and unique ecosystems, such as Antarctica and the Great Barrier Reef.

A number of the leading cruise companies reported on their approach to corporate citizenship and on their commitment to their employees. Carnival Corporation, for example, recognized 'the inextricable links between the health of our business and the vitality and sustainability of our communities' (Carnival Corporation, 2014, webpage). Further the company claimed to 'continually strive to contribute in a positive social, environmental and economic manner to our communities, working in conjunction with local governments, trade associations, tourism organizations and other community stakeholders' (Carnival Corporation, 2014, webpage). MSC Cruises provided a brief outline of its approach to 'social responsibility and sustainability' which claimed 'as a family company based on family values. With vast experience of sailing and respecting the world's waters MSC Cruises' social and environmental priorities are marine conservation, children, families and education' (MSC Cruises , 2014, webpage)

Royal Caribbean Cruises argued 'everything we do starts with our employees', 'we believe one of our greatest assets is our human capital' and that 'workforce engagement is critical to future success and an important part of how we bind the fabric of our culture' (Royal Caribbean Cruises, 2014, webpage). Royal Caribbean Cruises reported on its commitment to diversity, to creating an inclusive working environment and to its longstanding record in employing a multicultural workforce both on shore and at sea. The company also stressed its commitment to creating a working environment where employees are engaged and challenged and to providing all employees with a range of learning opportunities and development programmes. The company claimed its culture of development is reinforced through its promotion of a culture of open communication and through its performance management philosophy. Economic issues generally received more limited coverage in the reports and information that the leading cruise companies posted on sustainability but included employment creation, fostering partnerships with local traders and investment in local infrastructure and port facilities. The Carnival Corporation, for example, reported on its involvement in the development, enhancement and financing of port development in various parts of the world.

\section{Discussion}

Only two of the leading ocean and river cruise companies currently posted dedicated sustainability reports to detail how they managed the environmental, 
social and economic impacts of their business operations. The majority of cruise operators provided limited information on their approach to sustainability. This is not a problem per se in that companies have no statutory obligation to report on sustainability and as such this may reflect the reality that collectively the world's leading cruise companies are at the beginning of what may well be a long and demanding journey towards sustainability. That said a number of issues merit discussion and reflection.

Firstly, if 'developing a sustainable brand can help to manage reputational risks, enhance relationships with key stakeholders, and meet the requirements of a growing segment of consumers that place value on sustainability' (European Union et al., 2013, webpage) within the industry then the majority of cruise companies currently seem to be falling short of the mark in that they are not currently formally reporting on their sustainability strategies and achievements. More specifically reporting on sustainability may be important in helping to counter government, media and pressure group criticism. In January 2015, the UK newspaper The Guardian, for example, published an article entitled 'Murky Waters: the Hidden Environmental Impacts of Cruising.' (The Guardian, 2015, webpage) Friends of the Earth publish an annual 'Cruise Ship Report Card', and the 2014 version reported 'most travellers don't realize that taking a cruise is more harmful to the environment and human health than many other forms of travel' (Friends of the Earth, 2014, webpage). If the popularity of cruising continues to grow and if consumer, media, pressure group and government concerns about the environmental, social and economic impacts of cruising gain momentum then the majority of the leading cruise companies may be well advised to commit themselves to sustainability reporting in order not only to secure their market position but also to ensure long term competitiveness.

Secondly, there are issues about the way the cruise companies currently collectively implicitly construct both their definitions of sustainability and their sustainability agendas. Defining sustainability is not straightforward and there are a number of contrasting and contested meanings. Roper (2012, p. 72), for example, distinguished between 'weak' and 'strong' sustainability. While 'weak sustainability prioritises economic development, strong sustainability subordinates economies to the natural environment and society, without acknowledging ecological limits to growth' (Roper, 2012, p. 72). Many of the leading cruise companies stress their commitment to sustainability, albeit in varying measure, but their definitions of sustainability can be seen as being dominantly, but not exclusively, built around efficiency gains and the search for competitive advantage. As such they may be primarily driven by business continuity goals rather than by concerns for the environmental, social and economic impacts of their operations.

At the strategic level, for example, this is reflected in the 'Message from the Chairman and Chief Executive Officer' of Carnival Corporation at the beginning of their company's sustainability report. This message emphasised that 'our future is anchored by our singular mission; to deliver unmatched joyful vacation experiences and breakthrough shareholder returns by 
exceeding guest expectations and taking advantage of our scale' Carnival Corporation, 2014, webpage). At the operational level while many of the environmental initiatives reported by the cruise companies are designed to reduce energy and water use and waste generation they also reduce the cruise companies' operating costs. At the same time the cruise company's reported commitments to good working conditions, diversity, employment training, compensation and benefits and the role of women within the cruising industry, can all be seen to help to reduce employee turnover and to promote stability, loyalty and efficiency within the workforce.

Thirdly, there are issues around the underlying tensions between sustainability and continuing economic growth. In recent decades the cruising industry has experienced spectacular growth. With an eye to the future the sustainability reports published by Carnival Corporation and Royal Caribbean Cruises, for example, are couched within the idiom of continuing growth and business expansion and they reflected a belief in continuing consumption. Under the banner 'Enabling Responsible Growth' Royal Caribbean Cruises, for example, stressed that 'as our company grows in revenue and geographical reach, we aim to achieve responsible growth' and that 'as we visit each port we will be able to promote economic development through taxes, port fees, port development projects and most notably guest and crew spending at destinations' (Royal Caribbean Cruises, 2014, webpage). Royal Caribbean Cruises does not offer a definition of responsible growth per se but their approach is rooted in the general belief that continuing economic growth will inevitably be accompanied by the more efficient use of resources.

The concept of sustainable consumption, for example, which Cohen (2005, webpage) has described as 'the most obdurate challenge for the sustainable development agenda' is conspicuous by its absence in the sustainability reports and information posted by the leading cruise companies. In many ways both the concept and the practice of cruising, with its aim, for example, to 'enrich the guest experience through culinary, entertainment and technology enhancements' and its advertisements to 'Cruise the World in Luxury' (Royal Caribbean Cruises, 2014, webpage) can be seen as the very antithesis of sustainable consumption. That said the continuing popularity of cruising suggests little consumer appetite for sustainable consumption and here the European Commission's (2012, p. 19) recognition that 'sustainable consumption is seen by some as a reversal of progress towards greater quality of life' in that 'it would involve a sacrifice of our current, tangible needs and desires in the name of an uncertain future' resonates.

Finally, there are criticisms of the sustainability of the cruise industry drawn from a political economy perspective. On the one hand Sprague (2014, webpage) suggested that 'the cruise ship industry has become adept at repatriating more and more value from passenger spending, while at the same time maintaining a web of local and regional alliances that benefit from the industry.' Further, Sprague (2014, webpage) argued that 'the major companies in the cruise industry have come to embody what it means to be transnationalcircumventing borders and manipulating local economies in order to enrich 
the very few and sell exotic experiences to privileged sectors while at the same time generating very little benefit for those they exploit to achieve these ends.' Some of the ocean cruising companies, including Royal Caribbean Cruises, Norwegian Cruise Lines and Disney Cruises, either own or lease small islands, or areas of them, in the Caribbean. On these islands passengers are offered a range of service and leisure facilities including exclusive beach access, barbecue buffet lunches, water parks, parasailing, bars and shops and passengers can use their cruise card when purchasing goods and services on the islands thus effectively eliminating many benefits for local traders and reducing the economic benefits to the destination economy. More generally Mansfield (2009, p. 37), argued that conventional approaches to sustainability fail to recognise 'the political nature of the socio-economic processes that produce environmental degradation poverty and injustice.' In a similar vein, Castro (2004) has questioned the very possibility of sustainable development under capitalism and argued that economic growth relies upon the continuing and inevitable exploitation of both natural and social capital.

\section{Conclusions}

This exploratory review has revealed marked variations in the character, content and the extent to which the leading cruise companies are publicly reporting on how they look to manage the environmental, social and economic impact of their operations through their sustainability strategies. As sustainability becomes increasingly important in managing risk and reputation then a number of the leading cruise companies may need to reconsider their current approach to sustainability reporting if they are to retain, and ideally enhance, their position within what is a very competitive marketplace. More generally the authors would argue that current commitments to sustainability within the cruise industry and definitions of, and commitments to, sustainability can be interpreted as being primarily driven by business imperatives. The accent being on making efficiency gains across a wide range of economic, social and environmental issues rather than on maintaining the viability and integrity of natural ecosystems and on reducing demands on finite natural resources. More critically the authors suggest that the leading cruise companies' current commitments to sustainability are primarily couched within existing business models centred on continuing growth and consumption and that these commitments represent a weak approach to sustainability. As such this echoes Roper's (2012, p.72) belief that weak sustainability represents ' $a$ compromise that essentially requires very little change from dominant economic driven practices but effectively works to defuse opposition, increase legitimacy and allow business as usual.' 


\section{References}

Anderson, R. (1964) 'White Star', T. Stephenson \&Sons, Prescot, UK

Brida, J. G. and Zapata, S. (2010) Cruises Tourism: Economic, Socio-cultural and Environmental Impacts', International Journal of Leisure and Tourism Marketing', Vol. 1, no. 3, pp. 205-226

Butt, N. (2007) 'The impact of cruise ship generated waste on home ports and ports of call: A case study of Southampton', Marine Policy, Vol. 31. No 5, pp. 591-598

Carnival Corporation (2014) 'Sustainability from Ship to Shore', http://phx.corporateir.net/phoenix.zhtml?c=140690\&p=irol-sustainability_env (Accessed 14 April 2016)

Castro, C. (2004) 'Sustainable Development: Mainstream and Critical Perspectives', Organisation and Environment, Vol. 17, No.2, pp. 195-225.

Centres for Disease Control and Prevention (2016) 'Vessel Sanitation Programme: Cruise Ship Inspection', https://wwwn.cdc.gov/InspectionQueryTool/Inspe ctionResults.aspx (Accessed 8 August 2016)

Cohen, M.J. (2005) 'Sustainable consumption in a national context; an introduction to the symposium', available at http://ejournal.nbii.org/archives/vol1iss1/0410008.cohen.htmll last accessed (Accessed 16 November 2015)

Cruise Market Watch (2015) 'Market Share', http://www.cruisemarketwatch.com/ market-share/ (Accessed 23 November 2015)

Cruising the Past (2008) 'A Brief History of the Cruise Ship History', http://cruiseline history.com/a-brief-history-of-the-cruise-ship-industry/ (Accessed 4 August2016)

Deloitte (2012) 'Sustainability for Consumer Business Operations: A Story of Growth', available at https://www.google.co.uk/search?sclient=psy- 2016)ab\& site $=\&$ source $=\mathrm{hp} \& \mathrm{q}=$ Sustainability + for + Consumer + Business + Operations: $+\mathrm{A}+\mathrm{St}$ ory+of+Growth $\% \mathrm{E} 2 \% 80 \% 99 \% 2 \mathrm{C}+\&$ oq $=$ Sustainability+for+Consumer+Busines s+Operations:+A+Story+of+Growth\%E2\%80\%99\%2C+\&gs_l=hp.3...11401.114 01.0.13532.1.1.0.0.0.0.89.89.1.1.0.......1c..64.psy-

ab..1.0.0._pV6I3AuEfM $\&$ pbx $=1 \& b i w=1152 \& b i h=673 \& d p r=1 \& \mathrm{cad}=\mathrm{cbv} \&$ sei $=\mathrm{E}$ fxfVqqQGoatU8KSiuAJ (Accessed 3 December 2015)

Disney Cruise Line (2014) 'Environmental Overview', http://dclnews.com/wp-con tent/uploads/sites/4/2014/07/DCL_Env_Fact_2014.pdf?ts=1406230908 (Accessed 8 August 2016)

European Commission (2012) 'Policies to Encourage Sustainable Consumption', http: //ec.europa.eu/environment/archives/eussd/pdf/report_22082012.pdf (Accessed 3 February 2016)

European Union, Cruise Gateway North Sea and The Interreg IVB North Sea Region Programme (2013) 'Sustainable Cruise Tourism', http://archive.northsearegion. eu/files/repository/20130523174329_CruiseGateway_Best_practice_guide_Sustai nability_Summary.pdf (Accessed 30 November 2015)

Friends of the Earth (2014) '2014 Cruise Ship Report Card', http://www.foe.org/ cruise-report-card last accessed 30/11/2014 (Accessed 28 November 2015)

Howarth, D. and Howarth, S. (1986) 'The Story of P\&O', Weidenfeld and Nicholson, London.

Johnson, D. (2002) 'Environmentally Sustainable Cruise Tourism: A Reality Check', Marine Policy, No. 26, pp. 261-270

Klein, R. A. (2011) 'Responsible Cruise Tourism: Issues of Cruise Tourism and Sustainability', Journal of Hospitality and Tourism Management, Vol. 18, No. 1, p. $107-118$ 
Lubin, D.A. and Esty, D.C. (2010) 'The Sustainability Imperative', Harvard Business Review, Vol. 88, No. 5, pp.42-50

Luck, M., Maher, P. and Stewart, E.J (2010) 'Cruise Tourism in Polar Regions' Earthscan, London.

Mansfield, B. (2009) 'Sustainability' in 'A Companion to Environmental Geography', Eds. Castree, N., Demeriff, D., Liverman, D. and Rhoads, B., pp. 37-49, Wiley, London.

Market Realist (2015) 'A Key Overview of Carnival, the World's Largest Cruise Company’, http://marketrealist.com/2015/01/carnival-boasts-largest-market-sha re-cruise-passengers/ (Accessed 26 November 2015)

MSC Cruises (2014) 'Social Responsibility and Sustainability', http://m.msccruises. co.uk/uk_en/About-MSC-Cruises/Social-Responsibility/Overview.aspx (Accessed 14 April 2016)

Norwegian Cruise Lines (2014) 'Norwegians Make a Difference', https://www.ncl. com/press-releases/Norwegians-Make-a-Difference (Accessed 14 April 2016)

P\&O Cruises (2016) 'History of P\&O', https://www.pocruises.com.au/about/history (Accessed 4 August 2016).

Rodrigue, J-P. and Notteboom, T. (2013) 'The Geography of Cruises: Itineraries Not Destinations', Applied Geography. Vol. 18, No. 1, pp. 31-42

Roper, J. (2012) "Environmental Risk, Sustainability Discourses and Public Relations", Public Relations Inquiry, Vol.1 No.1, pp.69-87

Royal Caribbean Cruises (2014) 'Beyond the Horizon', http://media.royalcaribbean. com/content/en_US/pdf/RCL_2013_Sustainability_Report.pdf (Accessed 14 April 2016)

Sprague, J. (2014) 'Cruise Ships and Global Capitalism: The Industry's Shifting Political Economy', http://global-ejournal.org/2014/04/17/vol8iss2/ (Accessed 1 December 2015)

Statista (2015) 'Leading cruise companies worldwide by revenue in 2014', http://www.statista.com/statistics/243873/revenue-of-cruise-line-companies/ (Accessed 16 March 2016)

Stewart, E J.; Draper, D. (2006) 'Sustainable Cruise Tourism in Arctic Canada: An Integrated Coastal Management Approach', Tourism in Marine Environments, Vol.3, No 2, pp. 77-88

Sustainability Accounting Standards Board (2014) 'Cruise Lines: Sustainability Accounting Standards', http://www.sasb.org/wp-content/uploads/2014/12/ SV0205_Cruise_ProvisionalStandard.pdf (Accessed 3 November 2015)

The Guardian (2015) 'Murky Waters: The Hidden Environmental Impacts of Your Cruise', 5 January 2015, http://www.theguardian.com/sustainable-business/2015/ jan/05/cruise-ship-holidays-environmental-impact (Accessed 30 November 2015)

Wood, R. E. (2000) 'Caribbean Cruise Tourism', Annals of Tourism Research, Vol. 21, No. 3, pp. 345-370

World Tourism Organisation (2010) 'Cruise Tourism: Current Situation and Trends', https://pub.unwto.org/WebRoot/Store/Shops/Infoshop/4860/F69B/DDF8/6297/2 C04/C0A8/0164/E2F3/110111_cruise_tourism_excerpt.pdf (Accessed 23 November 2015) 
